\title{
INSTITUTIONAL SHAREHOLDING A MODERATOR TO AUDIT COMMITTEE CHARACTERISTICS AND EARNINGS MANAGEMENT OF LISTED CONGLOMERATE FIRMS IN NIGERIA
}

\author{
Abbas Umar \\ Department of Accounting \\ Kaduna State University (KASU)-Nigeria \\ Shehu Usman Hassan PhD \\ Department of Accounting \\ Kaduna State University (KASU)-Nigeria
}

\begin{abstract}
The relevance of audit committee characteristics in constraining managerial opportunistic tendencies has been explored by various researchers; the confrontational view in terms of the direction of their relationship has paint a vague picture which begs the introduction of other monitoring mechanism that may give a clear cut picture on direction of this relationship. This study uses two-stage least squares model and examines the impact of audit committee characteristics, institutional shareholding on discretionary accruals of listed conglomerate firms in Nigeria. Secondary data were extracted from the annual reports of 6 most active listed firms on the Nigerian Stock Exchange for the period 2006 to 2015. After running the OLS regression, a robustness test was conducted for validity of statistical inferences. A multiple regression was employed using HACC Model. The study documents that audit committee characteristic and institutional shareholding has significant impact on earnings management of the firms, specifically, audit committee size, audit committee financial expertise and institutional shareholding are inversely related with earnings management, while audit committee independence is positively and significantly related with earnings management, but there is no such impact of audit committee meetings. Furthermore, institutional shareholding and audit committee size are inversely related with earnings management; audit committee independence and institutional shareholding are positively, strongly and significantly constraining earnings management, while audit committee financial expertise with committees' meetings and institutional shareholding reveals no impact on earnings management. In line with the findings, the study recommended that regulatory bodies like CAMA, SEC, and NSE should ensure that listed conglomerate firms in Nigeria strictly adhere with code of best practice so that the interest of various stakeholder's would be fully protected.
\end{abstract}

KEYWORDS: Institutional Shareholding, Audit Committee, Earnings Management, Listed Conglomerate Firms, Nigeria

\section{Introduction}

Sound financial disclosure reduces agency problems by connecting the information asymmetry gap that exists between management and shareholders. Conversely, poor financial disclosure often misleads shareholders and has adverse effects on their wealth; the wave of recent financial reporting scandals validates this claim. The sharp disparity in disclosure outcomes across firms, the reasons some firms choose 
to exercise sound disclosure practices and others do not is vague. Therefore, identifying the factors affecting management's voluntary disclosure decisions is a fundamental research problem with implications for policy makers, the business community, and academics (Karamanou \& Vafeas, 2005).

The scandals and the crumple of some multi-national corporations across the globe such as Cendant Corp, Informix, McKesson HBO, Micro Strategy, Rite-Aid, Sunbeam Corp., Waste Management Inc., Enron, WorldCom to mention a few is as a result of the unethical Accounting practices. earnings manipulations is one of such unethically issues in Accounting that come under the umbrella of earnings management and serves as a tactical tool used by management under the excuse of maximizing firm's value and curbing risks. The loopholes in the application of Generally Accepted Accounting Principles (GAAP) gave birth to earnings manipulation.

The idea of Earnings management entails management inducement, influence or manipulation of reported earnings by subjective application of some specific accounting technique or changing methods; recognizing one-time non-current items, deferring or increasing expenses or revenue transactions or using other methods designed to influence short term earnings (Rahman \& Sharif, 2013). This practice causes attrition in the quality of earnings, and consequently the quality of financial reporting will lose out to delusion (Bala \& Kumai, 2015). Earnings management is not always alleged as wrong. Proponents of earnings management believed that there is a good side of earnings management and that it can be a signaling mechanism to convey inside information to the market, enabling share price to better reflect the firm's future prospects. The accounting profession has also accepted that not all earnings management techniques are misleading. However, the current accepted idea among accountants, regulators and standard setters is that, more often than not, earnings management is detrimental for it is used by managers to trick investors which dwindled the dependability of financial reporting (Uadiale, 2012).

Consequently, to curb the recent financial disclosure scandals, the U.S. Congress, the Securities and Exchange Commission (SEC), and the major stock exchanges focused on corporate boards as crucial vehicles for improving the quality of financial information provided by firms. In particular, standing board audit committees have come to the forefront of public attention because they are the core decision-making body that is expected to monitor the internal control and financial reporting practices. Blue Ribbon Committee's (1999) report a code of best practice for the functioning of corporate audit committees which is the initiative by the stock exchanges. As a result, the New York Stock Exchange (NYSE) has recently approved new corporate governance rules (SR-NYSE-2002-33). Similarly, aggravated by the SarbanesOxley Act of 2002, the SEC adopted new standards relating to listed company audit committees rule 338220 (Karamanou et al, 2005).

Audit committee is a sub-committee of the Board that specializes in, and is responsible for, ensuring the accuracy and reliability of the financial statements provided by management (Kuang, 2007). In Nigeria, section 359 (6) of the Companies and Allied Matters Acts CAMA (1990), laws of the federation of Nigeria, provide that the functions of audit committee are to review the audited and unaudited financial statements as well as other special investigation of the company in accordance with the legal requirement and agreed ethical practices and to ensure that the company maintains effective system of accounting and internal control as well as to review the scope and results of external auditors thereby reaffirming their objectivity.

Monitoring mechanisms other than Audit committee may reduce the level of earnings management. Investment institutions with substantial shareholding in a firm are believed to have the resources and incentives to monitor and influence management decision. Therefore, an increase in institutional shareholding is considered as an important channel via which minority shareholders are protected against expropriation of controlling shareholders in emerging markets (Oehl, 2000). However, it can be argued that if institutions hold a large amount of equity shares of a company, that in itself may exert an enormous pressure on the part of managers to manipulate earnings in order to please these institutions (Hassan \& Ahmed, 2012). Whether the institutions actually monitor and exert pressure on managers is an empirical question.

Nigeria is no exception to the global scandals and failure of corporations as evident by the Cadbury plc, Intercontinental Bank Plc, Oceanic Bank and the case of Arik air been taken over by AMCON. Cadbury

http://dx.doi.org/10.19085/journal.sijbpg041001 
Nigeria plc which was audited by Akintola Williams Delloite (AWD) saw it share price declined from \#86.52 per share to \#8.65 per share between the time frame of 4years (2005-2009) which led to it delisting from the Securities and Exchange Commission (SEC). The auditor and registrars (Union Registrars Limited) of Cadbury were call before Administrative Proceedings Committee (APC) of the Commission to defend themselves for violating the provisions of the Investment and Securities Act 1999, the SEC Rules and Regulations 2000 (as amended), Code of Conduct for Capital Markets Operators and their Employees and the code of Corporate Governance in Nigeria. Data obtained from the Nigerian Stock Exchange indicate that in July 2017, companies such as Beco Petroleum Product Plc, MTECH Communications Plc, MTI Plc, UTC Plc and Ashakacem Plc were delisted for regulatory issues which make it a round figure of 20 companies been delisted in 2016 to 2017 and a total of 90 companies within 2002 to 2017. This has brought about doubt in the minds of shareholders on the credibility and reliability of financial reports which begs the indulgence of researchers to investigate the effect of corporate governance mechanism on earnings management.

More so, the literature on the relationship between audit committee characteristics and earnings management is blessed with divergent outcomes and inconclusive. Some studies found positive relationships, while others found negative association and other researchers reported no relationship. These mix finding makes the direction of this relationship to be vague. It was argued that audit committee size plays a vital role in improving the quality of earnings. Some studies report that smaller audit committee are more efficient in monitoring the financial reporting process and reducing earnings management while others argued that more hands are better than few (Beasley \& Selterio, 2001). Furthermore, several studies support the negative relationship between audit committee independence and earnings management for example, (Klein, 2002) whereas other studies indicate that audit committee independence is positively and significantly associated with earnings management (Shah, Butt \& Hassan, 2009). Again, prior studies shown that audit committee financial expertise is negatively associated with earnings management (Sharma \& Kuang, 2013) while others indicated that financial expertise is not significantly related with earnings management.

Furthermore, different findings were established by previous studies that discussed the relationship between audit committee meetings and earnings management. Some studies reported that frequency of audit committee meeting is negatively associated to discretionary accruals (Chtourou, Bédard, \& Courteau, 2001) whereas others argued that meeting more than twice is positively associated with earnings management (Xie, Davidson III \& Dadalt, 2003). This study tends to address the confrontational association by moderating audit committee and earnings management with institutional shareholding. To protect their hug investment, investment institutions are concerned with the objectivity of the audited and unaudited financial report as well as the internal control system of the firm they invested in, thus, they lay much emphasis on ensuring that audit committee characteristics such as audit committee size, audit committee independence, audit committee financial expertise and audit committee meetings are in accordance with the best corporate practice as audit committees are the core corporate governance mechanism that is saddled with the responsibility of checkmating the aforementioned activities.

The main objective of this study is to empirically investigate the effect of institutional shareholding, audit committee characteristics on earnings management. Thus, the specific objectives are;

i. To determine the influence of audit committee size on earnings management of listed conglomerate firms in Nigeria.

ii. To find out the effect of audit committee independence on earnings management of listed conglomerate firms in Nigeria.

iii. To ascertain the extent to which audit committee financial expertise affects earnings management of listed conglomerate firms in Nigeria..

iv. To examine the influence of audit committee meetings on earnings management of listed conglomerate firms in Nigeria.

http://dx.doi.org/10.19085/journal.sijbpg041001 
v. To investigate the effect of institutional shareholding on earnings management of listed conglomerate firms in Nigeria.

In line with the objective of this study the following null hypotheses were formulated.

$\mathrm{H}_{01}$ Audit committee size has no significant effect on earnings management of listed conglomerate firms in Nigeria.

$\mathrm{H}_{02}$ Audit committee independence has no significant impact on earnings management of listed conglomerate firms in Nigeria.

$\mathrm{H}_{03}$ Audit committee financial expertise has no significant effect on earnings management of listed conglomerate firms in Nigeria.

$\mathrm{H}_{04}$ Audit committee meetings have no significant influence on earnings management of listed conglomerate firms in Nigeria.

$\mathrm{H}_{05}$ institutional shareholdings have no significant influence on earnings management of listed conglomerate firms in Nigeria.

This study is expected to contribute immensely to the existing literature. Even though there are a lot of literature on the audit committee characteristics and earnings management around the globe, to the best of the researcher's knowledge there is limited evidence from previous literature that empirically investigates the separate and joint effect of institutional shareholding, audit committee characteristics and earnings management of listed conglomerate firms in Nigeria. This will therefore serve as a reference for further researchers in this area, by critically looking at the empirical finding thereby discussing the implication from the Nigerian perspective. More so, The Government will find it very relevant, in the sense that earnings manipulation will in one way or the other affect the earnings of companies, which in turn affects their profit, from which the government is expected to receive its portion.

In order to achieve the above objectives, this paper is divided into five different sections. Section one is the introduction. It captures key elements relating to institutional shareholding, audit committee characteristics and earnings management in Nigeria. Section two is on theories underlying institutional shareholding, audit committee characteristics and how they relate with earnings management and literature review. Section three covers research methodology. Section four focuses on data presentation, analysis and discussion of findings relating to this study. Section five is on conclusion and recommendations emerging from the study.

\subsection{Theoretical Development and Practice}

In this section, related literature on institutional shareholding, audit committee and earnings management are reviewed and the theoretical framework for the study is presented.

\subsection{Audit Committee Size and Earnings Management}

Prior studies have documented conflicting results regarding the effect of audit committee size and earnings management. Using a sample of 8 listed and active companies on the Nigerian Stock Exchange, Bala et al (2015) investigates the relationship between audit committee characteristics and earnings management for the period between 2009-2014. They found a negative and significant between audit committee size and earnings management. This work focused on Food and Beverages Firms which has different governance structure from that of the conglomerate firms. Similarly, Fodio, Ibikunle and Oba (2013) examined the interaction between corporate governance mechanisms and reported earnings quality. 25 quoted insurance firms were selected during the period 2007-2010 using Yaro Yamane formula, they found a negatively and significantly associated between audit committee size and earnings management. This work uses SPSS software as tool of analysis which fails to give room for robustness test that will guide the selection of the best model to be reported. In the same vein, Lin and Hwang (2010) document a negative relationship 
between audit committee size and earnings management, using meta-analysis techniques to synthesize and evaluate the findings from the large number of existing studies on the determinants of earnings management. Though, this study was carried out in the situation of developed countries, hence the differences of economies and regulatory frameworks across the globe call for an examination into the context of developing countries such as Nigerian. Conversely, using a sample of 20 out 33 Malaysian GLCs firms for the period of 2003 to 2009, Nelson and Jamil (2011) investigated audit committees and financial reporting quality following the government transformation program in Malaysia. They underpinned their study with agency theory and resource dependence theory. The study shows a positive relationship between audit committee size and earnings management.

\subsection{Audit Committee Independence and Earnings Management}

Fodio et al (2013) examined the interaction between audit committee independence and earnings management using 25 Nigerian quoted insurance firms during the period 2007-2010. They found positive relationship between audit committee independence and discretionary accruals. This work uses SPSS software as tool of analysis which fails to give room for robustness test that will guide the selection of the best model to be reported. Similarly, Bala et al (2015) document a positively and significantly relationship between audit committee independence to earnings management, Using a sample of 8 listed and active companies on the Nigerian Stock Exchange for the period between 2007-2014. They adopted Modified Jones Model (1995) to measure earnings quality. This work focused on Food and Beverages Firms which has different governance structure from that of the conglomerate firms. Also, from another direction, Chtourou et al (2001) found independent non-executive directors who are not managers in other firms is negatively associated to both the absolute and positive levels of discretionary accruals. In order to increase the power of their tests they used two groups of US firms, one with relatively high and one with relatively low levels of discretionary accruals in the year 1996. They employed modified Jones (1991) cross-sectional model to estimate the discretionary component of the total accruals. They used chi-square for data analysis, which is a less effective technique for instituting causality and effect of a relationship.

\subsection{Audit Committee Financial Expertise and Earnings Management}

Using the role that an audit committee financial expert plays in mitigating earnings management for a broad sample of NYSE and NASDAQ firms in 2003, Carcello, Hollingsworth, Klein and Neal (2006) examined the effect Audit Committee Financial Expertise, Competing Corporate Governance Mechanisms, and Earnings Management; looked at various types of audit committee financial expertise. They found that accounting and certain types of non-accounting financial expertise reduce earnings management for firms with weak alternate corporate governance mechanisms and they also found that independent audit committee members with financial expertise are most effective in mitigating earnings management. The short fall of this study is that its results are based on data for only one year which however may change over time. Using meta-analysis techniques to synthesize and evaluate the findings from the large number of existing studies on the determinants of earnings management, Lin et al (2010) found a negative relationship between audit committee financial expertise and earnings management. However, this study was carried out in the context of developed countries, the differences of economies and regulatory frameworks across the globe call for an investigation into the Nigerian scenario. Contrarily Using Modified Jones model to measure discretionary accruals (as a proxy of earnings management) and the sample of 167 Firms, and 613 Firms all from the population of UK financial Time Stock Exchange as the study comprises of two empirical studies. Rohaida (2011) found significant and positive relationship between audit committee financial expertise and earnings management. This study was carried out in the situation of developed country; hence the differences of economies and regulatory frameworks across the globe call for an examination into the context of developing countries such as Nigerian.

\subsection{Audit Committee Financial Meetings and Earnings Management}

Chtourou et al (2001) found that audit committee composed only of independent directors that meets more than twice a year is positively associated with earnings management. They drew their sample from the the population of US firms that appear on Compustat in 1996. To increase the power of their tests, they used firms with the largest amount (both negative and positive) of discretionary accruals and firms with close to

http://dx.doi.org/10.19085/journal.sijbpg041001 
zero discretionary accruals. They used chi-square for data analysis, which is a less effective technique for instituting causality and effect of a relationship. In the same vein, using a sample of 282 firms from the S\&P 500 index of year 1992, 1994 and 1996. Xie, et al (2003) examined the roles of the board and audit committee on earnings management. They found that audit committee meeting frequently is associated with reduced levels of discretionary current accruals. The disparity in governance structures and regulatory frameworks call for an assessment of similar fact in the Nigerian scenario. Similarly, using two step regression to determine the discretionary accruals of 8 sampled listed and active companies on the Nigerian Stock Exchange for the period between 2007-2014. Bala et al (2015) found that meetings frequently has a positively and significantly relationship with earnings management. This work focused on Food and Beverages Firms which has different governance structure from that of the conglomerate firms.

Othman, Ishak, Arif and Aris (2014) examine the Influence of audit committee characteristics on voluntary ethics disclosure using the top 94 companies listed on Bursa Malaysia. The study employs content analysis and multiple linear regressions to look at the relationships between voluntary ethics disclosure and audit committee characteristics. They documented no significant positive relationship between frequency of audit committee meetings and voluntary ethics disclosure. The disparity in governance structures and regulatory frameworks call for an assessment of similar fact in the Nigerian scenario.

\subsection{Institutional Shareholdings and Earnings Management}

Yang, Chun and Ramadili (2009) examine the interaction between board structure and institutional ownership structure on earnings management. Using Modified Jones Model with cross sectional approach to determine abnormal current accruals of 613 sampled listed firms from 3 sectors (construction, industrial and consumer) of Bursa Malaysia for the period of 3 years (2001-2003). They observed no relationship between the proportion of institutional shareholders and the degree of earnings manipulation. The study might have revealed different result if conducted in the Nigerian scenario. Similarly, García-meca and Sánchez-ballesta (2009) examine the effect of corporate governance on earnings management: using metaanalysis to synthesize and evaluate the findings from 35 studies on the relationship between corporate governance and earnings management. They found that the overall meta-analysis of ten studies on institutional ownership and earnings management are non-significant. They divide the sample according to the sign of accruals (signed and absolute), They found a weakly positive association between signed accruals and institutional ownership whereas the relationship between the absolute value of accruals and institutional ownership is negative. From another direction, using the sample of 20 active quoted firms on the Nigerian Stock Exchange for the period between 2008-2010, Hassan et al (2012) investigated the effect of institutional investors on earnings management. They found that institutional investors have positive and a strong impact on earnings management. The study only covers a period of 3 years which fail to capture current issues such as the changes in the current corporate governance code of 2011 by the Nigeria Securities and Exchange Commission.

For the purpose of this research, agency theory is adopted. The theory involves a contract under which the owners/shareholders called principal engages the services of a controller/managers called agent(s) to perform some services on their behalf, where some powers of decision making are delegated to the agent (Jensen \& Meckling 1976). Hence it is expected of the agent(s) (managers) to carry out this fiduciary contract with utmost sense of transparency and accountability. This means that they are expected to ignore their selfish interest and act in such a manner that benefits the shareholders. Though, in practice, the existence of information asymetry that gives the managers information privilege which may lead to the violation of their principal agency arrangement as managers are tempted to use their positions for self benefits, thus the agency problem (Hassan et al, 2012). Audit committee is one of the important mechanisms put in place to align the interests of the agents and principals since their composition constitutes equal number of shareholders and managers/directors.

http://dx.doi.org/10.19085/journal.sijbpg041001 
Figure 1: Conceptual Framework

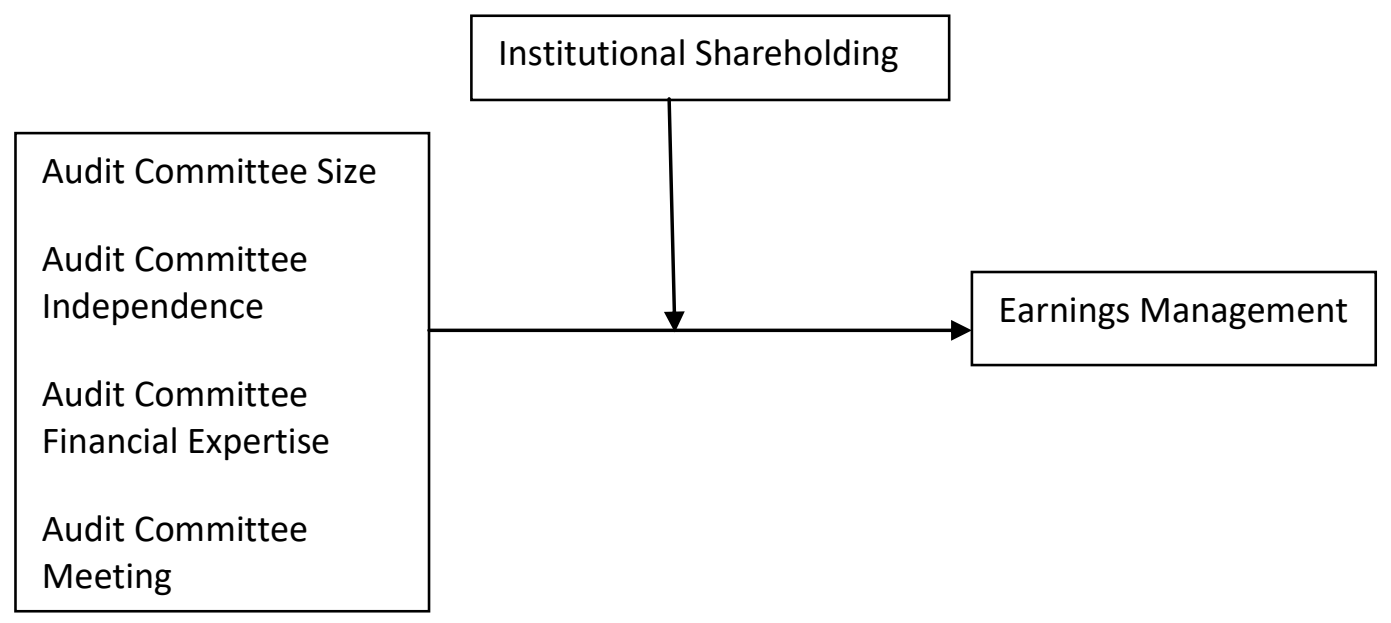

\section{Methodology and Data}

This work is a correlation research that links institutional shareholding, audit committee characteristics and discretionary accruals. The study consists of all the 6 listed conglomerate firms that are active on the Nigerian Stock Exchange as at 31st December, 2016 and whose data for the period of study, which is 20062015 are available. Thus, we have 60 firm-year observations. Secondary source of data was used to extract information from the annual report and accounts of selected firms between the period been studied. Multiple linear regression (two stage least square) were used as a technique of data analysis. The justification for this technique was that it has the ability to test the statistical association between two or more variables and allows for the prediction of the expected outcome.

Table 1 Variable Measurement

\begin{tabular}{|l|l|}
\hline Variables & Definition and Measurement \\
\hline Earnings Management & $\begin{array}{l}\text { Measured by absolute values of the residuals (discretionary } \\
\text { accruals) using Modified Jones model by Dehow, Sloan \& } \\
\text { Sweeney (1995). This will be explain bellow }\end{array}$ \\
\hline Audit Committee Size(ACSIZ) & Measured as the total number of audit committee members \\
\hline $\begin{array}{l}\text { Audit Committee Independence } \\
\text { (ACIDP) }\end{array}$ & $\begin{array}{l}\text { Proportion of non executive directors in the audit } \\
\text { committee to total number of the audit committee }\end{array}$ \\
\hline $\begin{array}{l}\text { Audit Committee Financial expertise } \\
\text { (ACFEP) }\end{array}$ & $\begin{array}{l}\text { Proportion of audit committee members with financial } \\
\text { expertise (financial knowledge) in the audit committee to } \\
\text { total number of the audit committee }\end{array}$ \\
\hline Audit Committee Meetings(ACMT) & $\begin{array}{l}\text { The number of meetings held by the audit committee } \\
\text { during the year }\end{array}$ \\
\hline Institutional Shareholding(IS) & $\begin{array}{l}\text { Proportion of shares owned by institutional shareholders to } \\
\text { total outstanding shares. }\end{array}$ \\
\hline
\end{tabular}

Source: Authors Review, 2018

A cross-sectional regression of the Modified Jones Model (1991) is utilized in this paper to estimate the discretionary accruals which represent the extent of earnings management. This model is selected because it has been found to be the most powerful, widely used and accepted model in detecting the earnings management practice (Dechow et al. 1995 and Adibah, Ismail, Kamarudin, Zijl, \& Dunstan, 2013). Total accrue (TACC)l is defined as the difference between net income (NI), which is the earnings before taxation and extraordinary item and cash flow from operating activities (OCF). Total accruals can be dissect into discretionary and non-discretionary accruals. Discretionary accruals represent subjective accounting choices made by managers whereas non-discretionary accruals depend on the level of activity of the firm. 
$\mathrm{TACC}_{\mathrm{it}}=\mathrm{NI}_{\mathrm{it}} \mathrm{OCF}_{\mathrm{it}} \ldots \ldots$

$\mathrm{TACC}_{\mathrm{it}} / \mathrm{TA}_{\mathrm{it}}=\alpha\left[1 / \mathrm{TA}_{\mathrm{it}}\right]+\beta_{1}\left[\left(\Delta \mathrm{REV}_{\mathrm{it}}-\Delta \mathrm{REC}_{\mathrm{it}}\right) / \mathrm{TA}_{\mathrm{it}]} \beta_{2}\left[\mathrm{PPE}_{\mathrm{it}} / \mathrm{TA}_{\mathrm{it}}\right]+\varepsilon_{\mathrm{it}}-\cdots-\right.$ - - (ii)

Where:

TACC $=$ is the total accruals (NI _ OCF)

$\mathrm{a}=$ Constant

$\beta=$ Beta

$\triangle \mathrm{REV}=$ is change in revenue

$\triangle \mathrm{REC}=$ is change in receivables

$\mathrm{PPE}=$ is property, plant and equipment

$\mathrm{TA}=$ total asset

$\mathrm{t}=$ time

$\mathrm{i}=$ firm

$\varepsilon=$ is the residual

After applying the modified Jones models, the discretionary accrual (DA) is the error term:

$\mathrm{DA}=\mathrm{TAC}_{\mathrm{it}} / \mathrm{TA}_{\mathrm{it}}-\left(\alpha\left[1 / \mathrm{TA}_{\mathrm{it}}\right]+\beta_{1}\left[\left(\Delta \mathrm{REV}_{\mathrm{it}}-\Delta \mathrm{REC}_{\mathrm{it}}\right) / \mathrm{TA}_{\mathrm{it}]}+\beta_{2}\left[\mathrm{PPE}_{\mathrm{it}} / \mathrm{TA} \mathrm{A}_{\mathrm{it}}\right]-\cdots-\right.\right.$ - - (iii)

The model that examines the hypotheses of the study is presented as follows:

$\mathrm{DA}_{\mathrm{it}}=\alpha+\beta_{1} \mathrm{ACSIZ}_{\mathrm{it}}+\beta_{2} \mathrm{ACINP}_{\mathrm{it}}+\beta_{3} \mathrm{ACFEP}_{\mathrm{it}}+\beta_{4} \mathrm{ACMT}_{\mathrm{it}}+\beta_{5} \mathrm{ISHR}_{\mathrm{it}}+\varepsilon_{\mathrm{it}}-\ldots-\ldots$

$\mathrm{DA}_{\mathrm{it}}=\alpha+\beta_{1}\left(\mathrm{ACSIZ}_{\mathrm{it}} * \operatorname{ISHR}_{\mathrm{it}}\right)+\beta_{2}\left(\mathrm{ACINP}_{\mathrm{it}} * \operatorname{ISHR}_{\mathrm{it}}\right)+\beta_{3}\left(\mathrm{ACFEP}_{\mathrm{it}} * \operatorname{ISHR}_{\mathrm{it}}\right)+\beta_{4}\left(\mathrm{ACMT}_{\mathrm{it}} * \operatorname{ISHR}_{\mathrm{it}}\right)+\varepsilon_{\mathrm{it}}$

(v)

Where:

$\alpha=$ Intercept

$\beta_{1}-\beta_{5}=$ parameters

$\mathrm{i} \mathrm{t}=$ firm $\mathrm{i}$ in time $\mathrm{t}$

ACSIZ= Audit committee size

ACINP $=$ Audit Committee Independence

ACFEP $=$ Audit Committee Financial Expertise

$\mathrm{ACMT}=$ Audit Committee meetings

ISHR= Institutional Shareholdings

$\varepsilon=$ error term (other factors that were not captured by the model)

\subsection{Results and Discussions}

This section covers the presentation, analysis and discussion of the results of the study. Results from the descriptive statistics of all the variables are presented, the correlation matrix and regression results are presented and discussed. Finally, the section closes with the implication of finding.

Table 2: Descriptive statistics

\begin{tabular}{|l|l|l|l|l|l|l|}
\hline & DCC & ACSIZ & ACIND & ACFEP & ACMT & ISHR \\
\hline Mean & 0.0699183 & 5.716667 & 0.3816667 & 0.2903333 & 3.583333 & 2.069018 \\
\hline Std. dev & 0.0656282 & 0.84556 & 0.1206503 & 0.1235213 & 1.02992 & 0.3661264 \\
\hline Minimum & 0.00454 & 4 & 0.17 & 0.17 & 2 & 1.622214 \\
\hline Maximum & 0.27207 & 9 & 0.6 & 0.6 & 6 & 2.886751 \\
\hline
\end{tabular}

Source: Extracted from STATA 13 Output

Table 2 shows that Discretionary accruals of listed conglomerates firm in Nigeria have a mean of 0.0699183 with standard deviation of 0.0656282 , Discretionary accruals also have minimum and maximum values of 0.00454 and 0.27207 respectively. The result indicates that the average manipulation of 
Discretionary accruals by managers in Nigerian conglomerate firms is 0.0699183 to 0.27207 . The minimum value Discretionary accruals value of 0.00454 implies that the lowest earnings management by managers is not serious to cause significant distortion in the financial statement. Audit Committee size average stood at 5.791667, ranging from 4 to 9 . Audit Committee Independence averages 0.3816667, lying between 0.17 and 0.6. The average of Committee Financial Expertise is 0.2903333 , ranging between 0.17 to 0.6. Audit Committee meetings averages 3.583333, ranging between 2 to 6 . The average of institutional shareholding is 2.069018 , lying between 1.622214 and 2.886751 . There is negligible dispersion of all the standard deviation from their mean, implying that the data is not skewed and is fit to produce a reliable result.

Table 3: Correlation Matrix

\begin{tabular}{|l|l|l|l|l|l|l|}
\hline & DCC & ACSIZ & ACIND & ACFEP & ACMT & ISHR \\
\hline DCC & 1.0000 & & & & & \\
\hline ACSIZ & -0.2671 & 1.0000 & & & & \\
\hline ACIND & 0.1530 & 0.0446 & 1.0000 & & & \\
\hline ACFEP & -0.1231 & 0.0171 & 0.3314 & 1.0000 & & \\
\hline ACMT & 0.1403 & 0.2125 & 0.0766 & -0.1708 & 1.0000 & \\
\hline ISHR & -0.1542 & 0.0450 & -0.0596 & -0.1156 & -0.0426 & 1.0000 \\
\hline
\end{tabular}

Source: Extracted from STATA 13 Output

From the Table 3 shows the correlation between all pairs of independent variables and the dependent variable in the model. It is observed that there is negative relationship between Discretionary Accruals and Audit Committee Size, Audit Committee Financial Expertise and institutional shareholding. This is inferred from the correlation coefficient of $-0.2671,-0.1231$ and -0.1542 respectively. This indicates that there are inverse relationships between audit committee size, audit committee financial expertise, institutional shareholding and earnings management of listed conglomerate firms in Nigeria. Similarly, it shows a positive association between Discretionary Accruals and Audit Committee Independence and Audit Committee Meetings which is evident by the correlation coefficient of 0.1530 and 0.1403 respectively.

Table 4: Robustness test

\begin{tabular}{|l|l|}
\hline Variables & \\
\hline Mean VIF & 1.14 \\
\hline Hettest $\mathrm{Chi}^{2}$ & 6.65 \\
\hline Hettest $\mathrm{Sig}$ & 0.0099 \\
\hline Hausman $\mathrm{Chi}^{2}$ & 0.30 \\
\hline Hausman Sig & 0.9995 \\
\hline LM Test Sig & 1.0000 \\
\hline
\end{tabular}

\section{Source: Extracted from STATA 13 Output}

Multicollinearity is conducted to check whether there is a correlation between independent variables which will mislead the result of the study. The variance inflation factor and the tolerance values are good measures of evaluating multicollinearity. The multicollinearity test using the variance inflation factor (VIF) pointed out that excessive correlation does not exist as all the factors are above 1.0 and all the tolerance values are below 10. The mean of the VIF stood at 1.14. The result is not shown for brevity. Considering the nature of the domain conglomerate, the study further tested for linearity between the moderator and earnings management. The test indicates that their relationship is inverse which call for transforming the moderator using inverse square root. Test for heteroscedasticity was conducted to check whether the variability of error terms is constant or not. The result of the test reveals that there is a presence of heteroscedasticity because the hottest chi2 (1) is 6.65 with a probability of 0.0099 which is statistically significant at $1 \%$ indicating that the data are not homoscedastic but heteroscedastic. This therefore suggests that the original OLS regression will not suit the study.

However, as a result fixed effect model was ran which suggest that this work should interpret the result of the random effect model because the Hausman test is not significant at any level of significant (0.9995). 
LM test is conducted in order to be guided in deciding which regression model best fit the study between the random effect regression model result and the OLS regression model result. This is because there is no significant difference between the two regression models. However, the result of the LM test with a chibar2 significant of 1.0000 suggests that OLS regression model best suits the study which leads this work to run for HACC model that correct for heteroscedasticity and Auto-correlation which is meant to be suitable. The reason for the presence of heteroscedasticity in the model is because of the significant difference in the businesses been conduct by conglomerates and also the difference in world corporate governance which each business will adopt that best suit the nature of their operations.

Table 5: Summary of Regression Result

\begin{tabular}{|l|l|l|l|l|}
\hline Variables & Coefficient & Z-value & P-value & $\begin{array}{l}\text { Model } \\
\text { summary }\end{array}$ \\
\hline Intercept & 0.224812 & 3.40 & 0.001 & \\
\hline ACSIZ & -0.0246144 & -2.97 & 0.003 & \\
\hline ACIND & 0.1081484 & 1.70 & 0.089 & \\
\hline ACFEP & -0.1169688 & -1.84 & 0.066 & \\
\hline ACMT & 0.0099577 & 1.23 & 0.218 & \\
\hline ISHR & -0.0291568 & -1.74 & 0.081 & \\
\hline R-square & & & & 0.2964 \\
\hline Wald Chi ${ }^{2}$ & & & & 19.75 \\
\hline Prob. Chi $^{2}$ & & & & 0.0014 \\
\hline
\end{tabular}

Source: Extracted from STATA 13 Output

\subsection{Audit Committee Size and Earnings Management}

Table 5 reveals that Audit Committee Size has a Z-value of -2.97 and a beta coefficient of -0.0246144 which is significant at $1 \%$. This signifies that Audit Committee Size is negatively and statistically impacting on earnings management of listed conglomerate firms in Nigeria. This implies that, $1 \%$ increase in the Audit Committee Size will lead to a decrease in earnings management of listed conglomerate firms in Nigeria by $2.46 \%$. Thus, the result is not surprising because larger Audit committees will provide a robust scrutiny of financial statement provided by management; guarantee that the company maintains effect system of accounting and internal control as well as reviewing the scope and result of the external auditors to ensure their objective. It can therefore be concluded that large Audit committee Size in the Nigerian conglomerate firms helps to mitigate the agency problem. Consequently, this result produce a basis for reject the first null hypothesis formulated which presumed that audit committee size has no significant effect on earnings management of listed conglomerate furms in Nigeria. This finding extends the finding of Bala et al (2015) they documented that audit committee size have a negative and significant associated with earnings management Using a sample of 8 listed and active Food and Beverages Firms in Nigeria for the period between 2009-2014. It is also support the findings Fodio et al (2013) and Lin et al (2010) whereas Nelson et al (2011) are of contrary opinion.

\subsection{Audit Committee Independence and Earnings Management}

Table 5 shows that audit committee independence is positively and significantly associated with earnings management of conglomerate firms in Nigeria with Z-value of 1.70 and beta coefficient of 0.1081484 which is at $10 \%$ level of significance. This implies that for every $1 \%$ increase of non executive directors in the audit committee the earnings management of listed conglomerate firms of Nigeria will also increase by $10.8 \%$. This signifies that audit committee independence may not serve as a means of reducing earnings manipulation by managers. This is not surprising as it is within the researcher's prior expectation. In Nigeria, as most independent audit committee are not financially literate and don't have the requisite expertise which will allow effective monitoring. The result oppose agency theory which argues as the presence of non executive directors (as agents) in the audit committee is suppose to align the interest of the managers and that of the shareholders which will curb the agency problem. However, this result serves as a justification for the rejection of the second null hypothesis formulated which stated that audit committee independence has no significant impact on earnings management of listed conglomerate firms in Nigeria.

http://dx.doi.org/10.19085/journal.sijbpg041001 
The finding is contrary to Chtourou et al (2001) whereas it extends the findings of Fodio et al (2013) and Bala et al (2015).

\subsection{Audit Committee Financial Expertise and Earnings Management}

To test hypothesis three which state that audit committee financial expertise has no significant effect on earnings management of listed conglomerate firms in Nigeria. Table 5 reveals a Z-value of -1.84 and a beta coefficient of -0.1169688 which is at $10 \%$ level of significance. This signifies that audit committee financial expertise has negative, statistical and significant impact on earnings management of listed conglomerate firms in Nigeria. This implies that, $1 \%$ increase in audit committee member with financial expertise will decrease earnings management of listed conglomerate firms in Nigeria by $11.7 \%$. The result is not far away from reality as audit committee that are financially literate provide a better checkmate of financial statements and recommend a better accounting and internal control system that will deter the opportunistic behaviors of managers, thus, it validates agency theory. This provides an evidence for rejecting the third hypothesis. The finding is consistent with that of Carcello et al (2006) and Lin et al (2010), also in contradiction of Ruhaida (2011).

\subsection{Audit Committee Financial Meetings and Earnings Management}

Table 5 provides evidence of an insignificant positive relationship between audit committee financial meetings and earnings management of listed conglomerate firms in Nigeria. This can be deduced from the beta coefficient of 0.0099577 and Z-value of 1.23, which is not significant at any level. This insignificance association indicates that audit committee financial meeting is not in any way contributing to earnings management of conglomerate firms in Nigeria. This result contradicts the prior expectation of the researcher as audit committee members frequent meeting is supposed to give room for the members to use their gumption and knowledge to scrutinize the audited and unaudited financial statement as well as checkmating the internal control and system of accounting been adopted by the listed conglomerate firms in Nigeria and also to provide a financial statement that can be relied upon by various stakeholders. This result serves as an evidence for failure to reject the fourth hypothesis. This contradicts the finding of Chtourou et al (2001), Xie, et al (2003) and Bala et al (2015), also in support of Othman et al (2014).

\subsection{Institutional Shareholdings and Earnings Management}

In addition, the result in table 5 shows that institutional shareholding has a Z-value of -1.74 and a beta coefficient of -0.0291568 which is significant at $10 \%$. This signifies that institutional shareholding is negatively and statistically influencing earnings management of listed conglomerate firms in Nigeria. This implies that for any $1 \%$ increase in the number of shares held by institutions will lead to a decrease in earnings management of listed conglomerate firms in Nigeria by $2.92 \%$. This revelation is hardly surprising judging from the fact that institutions holding substantial shares in a firm would have no other choice but to deploy all it resources, skills and incentives to monitor and constrain management opportunistic tendencies, hence, interest of both existing and prospective stakeholders will be covered. Thus, validating agency theory. This result provide a basis of rejecting hypothesis five of the study which state that institutional shareholding has no significant impact on earnings management of listed conglomerate firms in Nigeria. This finding extend the finding of Hassan et al (2012), also in support of Yang et al (2009) and Garcíameca et al (2009).

Overall, the combined impact of the regressors (audit committee size, audit committee independence, audit committee financial expertise, audit committee meetings and institutional shareholding) on earnings management of listed conglomerate firms in Nigeria, is shown on the model summary of the regression results. The Wald Chi2 of 19.75 which is significant at $1 \%(0.0014)$ reveals that the model is well fitted and that the study findings can be relied upon, while the R-square suggests that the regressors are able to explain regress and (discretionary accruals) to the extent of 30\% (approximately), the remaining $70 \%$ are explained by other factors that are not captured in the model. 
Table 6: Regression results with Moderator

\begin{tabular}{|l|l|l|l|}
\hline Variable & Coefficient & Coefficient & P-value \\
\hline ACSIZ & -0.0246144 & & 0.003 \\
\hline ACIND & 0.1081484 & & 0.089 \\
\hline ACFEP & -0.1169688 & & 0.066 \\
\hline ACMT & 0.0099577 & & 0.218 \\
\hline ISHR & -0.0291568 & & 0.081 \\
\hline ACSIZISHR & & $\mathbf{- 0 . 0 4 4 5 1 7 5}$ & $\mathbf{0 . 0 9 7}$ \\
\hline ACINDISHR & & $\mathbf{0 . 0 5 5 0 0 9 5 1}$ & $\mathbf{0 . 0 5 7}$ \\
\hline ACFEPISHR & & $\mathbf{- 0 . 3 4 5 4 4 5 9}$ & $\mathbf{0 . 2 2 8}$ \\
\hline ACMTISHR & & $\mathbf{0 . 0 4 2 7 8 0 1}$ & $\mathbf{0 . 1 9 6}$ \\
\hline
\end{tabular}

Source: Extracted from STATA 13 Output

\subsection{Audit Committee Size, Moderator and Earnings Management}

Audit committee size and earnings management before the introduction of the moderator has a beta coefficient of -0.0246144 which was significant at $1 \%$, indicated by a P-value of 0.003 . However, after the introduction of the moderator the relationship dwindled a little bit showing a beta coefficient of -0.0445175 and a P-value of 0.097 which is at $10 \%$ level of significance. Even with the fact that the significance level escalated from $1 \%$ to $10 \%$, the result from table 6 indicate that investment institutions as monitoring mechanism has an effect on audit committee size that helps in reducing the opportunistic tendencies of managers as they ensure that conglomerates strictly adhere with the provision of Companies and Allied Matters act CAMA (2004) of having equal representation of shareholders and directors giving the committee the required balance to capture both the interest of the shareholders and that of the directors. Thus, agency problem will be solved.

\subsection{Audit Committee Independence, Moderator and Earnings Management}

Audit committee independence and earnings management without the moderator has a beta coefficient of 0.1081484 and a P-value 0.089 which is statistically significant at $10 \%$. When the moderator was introduced the result shows a beta coefficient of 0.05500951 which is significant at $10 \%$, indicated by a Pvalue of 0.057 . The result in table 6 reveal that the relationship between audit committee independence and earnings management did not change even with the introduction of institutional investors as a monitoring mechanism. This shows that even with the fact that non-executive directors possess no interest as they don't take part in the day to day management of the firms been studied, they may lack the required financial knowledge and industrial experience that is needed to curb the opportunistic tendencies of managers.

\subsection{Audit Committee Financial Expertise, Moderator and Earnings Management.}

Audit committee financial expertise and earnings management has a negative, statistical and significant association before the introduction of the moderator; this can be deduced from a beta coefficient of 0.1169688 and a P-value of 0.066 which is significant at $10 \%$. The beta coefficient of -0.3454459 and a Pvalue of 0.228 shows the presence of a negative and insignificant relationship with the introduction of the moderator. This indicates that investment institutions have an undue influence on the integrity of members on the audit committee with financial knowledge which affect their objectivity that made them not to bat an eye on the opportunistic behaviors of managers of conglomerate firms in Nigeria. This supported the argument that investment institutions are short-term minded which enable them go any lent in employing their numerous resources to protect their investments.

\subsection{Audit Committee meetings, Moderator and Earnings Management.}

Table 6 shows that before the moderator was introduced, audit committee meetings and earnings management has a positive and insignificant relationship which is observed by the beta coefficient of 0.0099577 with a P-value of 0.218 . When the moderator was introduced the result was still the same as a 
beta coefficient of 0.0427801 and a P-value of 0.196 was obtained from table 6 which also indicate that there is a positive and insignificant relationship between audit committee meetings, institutional shareholding and earnings management. This implies that even though investment institutions are supposed to have the resources and incentives to monitor and influence management decision, meetings more than five times do not guarantee better monitoring of earnings management of listed conglomerate firms in Nigeria. This is because it can be observed that audit committees of the sampled firms met two to six times within the period of the study.

\section{Conclusion and Recommendations}

This study examines the interaction between four aspects of audit committee characteristics, institutional shareholding and discretionary accruals of listed conglomerate firms in Nigeria. Consequently, based on the findings of the study the following conclusions are drawn.

i. The study concludes that, the observed negative significant relationship between audit committee size and earnings management of listed conglomerate firms in Nigeria with and without the monitoring effect of institutional shareholders was due to the fact that larger audit committee with equal representation are expected to compose experience personnel who will be eligible to come up with useful strategies to be implemented that will serve as guide against earnings management. However, it is believed that with good strategies both existing and prospective stakeholder's interest will be covered.

ii. The study concludes that, the appearance of positive significant association between audit committee independence, institutional shareholding and earnings management of listed conglomerate firms in Nigeria explains the believe that non executive directors may not have the requisite financial sophistication and industrial experience that can aid in deterring earnings management.

iii. The study conclude that, the presence of negative significant relationship between audit committee financial expertise and earnings management of listed conglomerate firms in Nigeria before the introduction of the moderator and the presence of a negative insignificant interaction when the moderator was introduced indicate that to protect their short-term mindedness investment institutions influenced the integrity of members on the audit committee with financial knowledge which affect their objectivity.

iv. The study conclude that, the existence of a positive insignificant relationship between audit committee meetings, institutional shareholding and earnings management of listed conglomerate firms in Nigeria is consistent with the evidence that audit committees meetings more than twice will not result in more effective monitoring even with the resources and incentives of institutional investors.

v. Finally, the study concludes that, the presence of a negative but significant relationship between institutional shareholding and earnings management listed conglomerate firms in Nigeria indicate that investment institutions will employ the necessary resources to protect their investment which will dwindled the earnings management provided by managers.

In line with the findings and the conclusions of the study, the following recommendations are made: Regulatory bodies like CAMA, SEC, and NSE should ensure that listed conglomerate firms in Nigeria strictly adhere with code of best practice so that the interest of various stakeholder's would be fully protected.

i. The individual and institutional shareholders of listed conglomerate firms in Nigeria should ensure strict compliance with the provision of having six members equal representation (three shareholders and three directors) as proposed by Companies and Allied Matters act CAMA (2004), because it is observed that some of the firms been studied at a particular period of time have only four audit committee members. SEC and other regulatory bodies should providing a fine or penalty on any company that is found wanting of not abiding strictly by these rules and regulations.

ii. SEC and NSE should clearly spell out the composition of audit committee members so as to enable them carry out their functions effectively. Instead of dwelling laying much emphasis on independence, It should be in such a way that independent members should have financial knowledge and specific industrial experience.

http://dx.doi.org/10.19085/journal.sijbpg041001 
iii. The minimum number of members with financial expertise in the audit committees should be increased for better checkmating of financial report presented by managers to reduce their opportunistic tendencies and also avoid undue influence of investment institutions. SEC and other regulatory bodies should make it compulsory that the chairman of the audit committee should be a person with requisite financial background or professional accountant.

iv. There is the need for regulators like SEC to have a stand on the maximum number of meetings to be held by audit committees as it is not the number of meetings that determine the monitoring of the opportunistic attitude of managers but the intelligence of the members to understand the economic implications of management decisions.

v. Regulatory authorities should emphasize the need for participation of investment institutions in firms. They help to mitigate the agency problems, thereby aligning the interest of the managers and that of the shareholders.

\section{REFERENCES}

[1] Adibah, W., Ismail, W., Kamarudin, K. A., Zijl, T. Van, \& Dunstan, K. (2013). Earnings quality and the adoption of IFRS-based accounting standards: Evidence from an emerging market. International Journal of Accounting, 21(1), 53-73. https://doi.org/10.1108/13217341311316940

[2] Bala, H., \& Kumai, G. B. (2015). Audit committee characteristics and earnings quality of listed food and beverages firms in Nigeria. International Journal of Accounting, Auditing and Taxation, 2(8), 1-13.

[3] Beasley, M.S., \& S.E., Salterio.( 2001). The relationship between board characteristics and voluntary improvements in audit committee composition and experience. Contemporary Accounting Research. 18 (4): 539-570.

[4] Carcello, J. V, Hollingsworth, C. W., Klein, A., \& Neal, T. L. (2006). Audit committee financial expertise, competing corporate governance mechanisms, and earnings management.

[5] Chtourou, S. M., Courteau, J., \& Lucie, B. (2001). Corporate governance and earnings management. http://papers.ssrn.com/abstract=275053, 4(418), 1-39.

[6] Dechow, P.M., R.G. Sloan, \& A.P. Sweeney. (1995). Detecting earnings management. The Accounting Review 70 (2): 193-225.

[7] Fodio, M. I., Ibikunle, J., \& Oba, V. C. (2013). Corporate governance mechanisms and reported earnings quality in listed Nigerian insurance firms. International Journal of Finance and Accounting, 2(5), 279-286. https://doi.org/10.5923/j.ijfa.20130205.01

[8] García-meca, E., \& Sánchez-ballesta, J. P. (2009). Corporate governance and earnings management : A metaanalysis. An International Review, 17(5), 594-610. https://doi.org/10.1111/j.1467-8683.2009.00753.x

[9] Hassan, S. U., \& Ahmed, A. (2012). Intitutional investors and discretionary accruals: The case of listed manufacturing firms in Nigeria. International Journal of Advanced Research in Management and Social Sciences, 1(1), 1-16.

[10] Irene Karamanou and Nikos Vafeas. (2005). The association between corporate boards , audit committees , and management earnings forecasts: An empirical analysis. Journal of Accounting Research, 43(3), 1-34. https://doi.org/10.1111/j.1475-679X.2005.00177.x

[11] Jensen, M., \& Meckling, W., (1976). Theory of the firm: Managerial behaviour, agency costs and ownership structure. Journal of Finance and Economics, 3, 305-360

[12] Klein, A. (2002), "Audit committee, board of director characteristics and earnings management", Journalof Accounting and Economics 33, 375-400.

[13] Kuang, C. (2007). Audit committee characteristics and earnings management in New Zealand.

[14] Lin, J. W., \& Hwang, M. I. (2010). Audit quality , corporate governance, and earnings management: A meta-analysis. International Journal of Auditing, 14(77), 1-21. https://doi.org/10.1111/j.10991123.2009.00403.x

[15] Nelson, S. P., \& Jamil, N. N. (2011). Audit committees and financial reporting quality following the government transformation program : Evidence from MALAYSIA, 2007(January), 1-11.

[16] Othman, R., Ishak, I. F., Arif, S. M. M., \& Aris, N. A. (2014). Influence of audit committee characteristics on voluntary ethics disclosure. Procedia - Social and Behavioral Sciences, 145, 330-342. https://doi.org/10.1016/j.sbspro.2014.06.042

[17] Rahman, M., \& Sharif, J. (2013). Techniques , motives and controls of earnings management. International Journal of Information Technology and Business Managent, 11(1), 1-13.

[18] Rohaida. B. (2011). The relationship between governance practices, audit quality and earnings management. UK Evidence, Durham E-theses, Durham University. http://etheses.dur.ac.uk/1382/

[19] Shah, S. Z. A; Butt, A. S; \& Hassan, A. (2009). Corporate governance and earnings 
Management: an empirical evidence from Pakistani listed companies, European Journal of Scientific Research, 26 (4), 624-638

[20] Sharma, V. D., \& Kuang, C. (2013). Voluntary audit committee characteristics , incentives , and aggressive earnings management: Evidence from New Zealand. International Journal of Accounting, 5(1), 1-14. https://doi.org/10.1111/ijau.12013

[21] Uadiale, O. M. (2012). Earnings management and corporate governance in Nigeria. Research Journal of Finance and Accounting, 3(3), 1-11.

[22] Xie, B., Davidson III, W.N., \& DaDalt, P.J., (2003). Earnings management and corporate governance: The role of the board and the audit committee. Journal of Corporate Finance, Vol. 9, pp. 295-316

[23] Yang, W. S. H. I., Chun, L. O. O. S. I. N., \& Ramadili, M. (2009). The effect of board structure and institutional ownership structure on earnings management earnings management with board structure. International Journal of Economics and Management, 3(2), 332-353. 


\section{APPENDEIX}

\section{LISTED CONGLOMERATE FIRMS IN NIGERIA AS AT 31/12/2017.}

1.

2.

3.

4.

5.

6.
A.G. LEVENTIS NIGERIA PLC

CHELLARAMS PLC.

JOHN HOLT PLC.

S C O A NIG. PLC.

TRANSNATIONAL CORPORATION OF NIGERIA PLC U A C N PLC.

\begin{tabular}{r|rrrrr} 
Variable & Obs & Mean & Std. Dev & Min & Max \\
\hline dcc & 60 & .0699183 & .0656282 & .00454 & .27207 \\
acsiz & 60 & 5.716667 & .84556 & 4 & 9 \\
acind & 60 & .3816667 & .1206503 & .17 & .6 \\
acfep & 60 & .2903333 & .1235213 & .17 & .6 \\
acmt & 60 & 3.583333 & 1.02992 & 2 & 6 \\
\hline Invs_SQRT & 60 & 2.069018 & .3661264 & 1.622214 & 2.886751
\end{tabular}

\begin{tabular}{r|ccccc} 
Variable & Obs & $\operatorname{Pr}($ Skewness) & Pr(Kurtosis) & adj chi2(2) & Prob>chi2 \\
\hline dcc & 60 & 0.0002 & 0.0481 & 14.38 & 0.0008 \\
acsiz & 60 & 0.0003 & 0.0009 & 18.32 & 0.0001 \\
acind & 60 & 0.9295 & 0.0285 & 4.79 & 0.0913 \\
acfep & 60 & 0.0064 & 0.8503 & 6.80 & 0.0334 \\
acmt & 60 & 0.6042 & 0.5507 & 0.64 & 0.7259 \\
Invs_SQRT & 60 & 0.0610 & 0.1037 & 5.82 & 0.0544
\end{tabular}

\begin{tabular}{r|rrrrrr} 
& dcc & acsiz & acind & acfep & acmt Invs_S T \\
\hline dcc & 1.0000 & & & & & \\
acsiz & -0.2671 & 1.0000 & & & & \\
acind & 0.1530 & 0.0446 & 1.0000 & & & \\
acfep & -0.1231 & 0.0171 & 0.3314 & 1.0000 & & \\
acmt & 0.1403 & 0.2125 & 0.0766 & -0.1708 & 1.0000 & \\
Invs_SQRT & -0.1542 & 0.0450 & -0.0596 & -0.1156 & -0.0426 & 1.0000
\end{tabular}

\begin{tabular}{r|crc} 
Source & SS & df & MS \\
\hline $\begin{array}{r}\text { Model } \\
\text { Residual }\end{array}$ & .04476706 & 5 & .008953412 \\
\hline Total & .25449567 & 54 & .003876844 \\
\hline
\end{tabular}

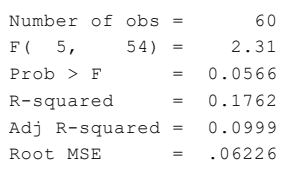

\begin{tabular}{r|rrrrrr}
\hline dcc & Coef. & Std. Err. & $t$ & P>lt & & [95\% Conf. Interval] \\
\hline acsiz & -.0232147 & .0098459 & -2.36 & 0.022 & -.0429546 & -.0034749 \\
acind & .1112985 & .071964 & 1.55 & 0.128 & -.0329806 & .2555776 \\
acfep & -.0936458 & .0716802 & -1.31 & 0.197 & -.2373559 & .0500643 \\
acmt & .0096846 & .008287 & 1.17 & 0.248 & -.0069299 & .026299 \\
Invs_SQRT & -.0255277 & .0223816 & -1.14 & 0.259 & -.0704 & .0193447 \\
_cons & .205453 & .0796139 & 2.58 & 0.013 & .0458367 & .3650692 \\
\hline
\end{tabular}




\begin{tabular}{|c|c|c|c|c|c|c|}
\hline Variable & VIF & $1 / \mathrm{VIF}$ & & & & \\
\hline acfep & 1.19 & 0.838194 & & & & \\
\hline acind & 1.15 & 0.871644 & & & & \\
\hline $\mathrm{acm} t$ & 1.11 & 0.902032 & & & & \\
\hline $\operatorname{acsiz}$ & 1.05 & 0.948040 & & & & \\
\hline Invs_SQRT & 1.02 & 0.978548 & & & & \\
\hline Mean VIF & 1.11 & & & & & \\
\hline \multicolumn{7}{|l|}{. hettest } \\
\hline \multicolumn{7}{|c|}{$\begin{array}{l}\text { Breusch-Pagan / Cook-Weisberg test for heteroskedasticity } \\
\text { Ho: Constant variance } \\
\text { Variables: fitted values of dcc }\end{array}$} \\
\hline $\operatorname{chi2}(1)$ & 1) & 8.33 & & & & \\
\hline \multicolumn{2}{|c|}{ Prob > chi2 } & 0.0039 & & & & \\
\hline Fixed-effects & (within) reg & \multicolumn{2}{|c|}{ ) regression } & Number $\circ$ & of obs & $=$ \\
\hline \multicolumn{4}{|c|}{ Group variable: firm } & Number $\circ$ & of groups & $=$ \\
\hline \multirow{4}{*}{$\begin{array}{l}\text { between } \\
\text { overall }\end{array}$} & $=0.1305$ & & & Obs per & group: min & $=$ \\
\hline & $=0.8319$ & & & & avg & 10.0 \\
\hline & $=0.1757$ & & & & $\max$ & 10 \\
\hline & & & & $E(5,49)$ & & 1.47 \\
\hline $\operatorname{corr}\left(u_{-} i, x b\right)$ & $=0.2228$ & & & Prob > F & & 0.2166 \\
\hline dcc & Coef. & Std. Err. & t & $P>|t|$ & [95\% Conf & f. Interval] \\
\hline $\operatorname{acsiz}$ & -.0214387 & .0110609 & -1.94 & 0.058 & -.0436664 & .000789 \\
\hline acind & .0985171 & .0910093 & 1.08 & 0.284 & -.0843729 & .2814071 \\
\hline acfep & -.0891377 & .0837681 & -1.06 & 0.292 & -.257476 & .0792005 \\
\hline $\mathrm{acm} t$ & .0085587 & .0087869 & 0.97 & 0.335 & -.0090992 & .0262166 \\
\hline Invs_SQRT & -.0269714 & .0240463 & -1.12 & 0.267 & -.0752942 & .0213514 \\
\hline cons & .205891 & .0843104 & 2.44 & 0.018 & .0364629 & .3753191 \\
\hline sigma_u & .00876587 & & & & & \\
\hline sigma_e & .06481173 & & & & & \\
\hline rho & .01796428 & (fraction & of varia & hce due to & u_i) & \\
\hline
\end{tabular}

$\begin{array}{lll}\text { F test that all u_i=0: } & F(5,49)=0.17 \quad \text { Prob }>F=0.9733\end{array}$

\begin{tabular}{|c|c|c|c|c|c|c|c|}
\hline Random-effects & GLS regres. & & & Number & of obs & $=$ & 60 \\
\hline Group variable: & firm & & & Number $\circ$ & of group & ps & $=$ \\
\hline R-sq: within & $=0.1300$ & & & Obs per & group: & $\min =$ & 10 \\
\hline between & $=0.8419$ & & & & & $\mathrm{avg}=$ & 10.0 \\
\hline overall & $=0.1762$ & & & & & $\max =$ & 10 \\
\hline & & & & Wald chi & i2 (5) & $=$ & 11.55 \\
\hline $\operatorname{corr}\left(u_{-} i, x\right)$ & $=0$ (assume & & & Prob $>c$ & $\operatorname{chi} 2$ & $=$ & 0.0415 \\
\hline dec & Coef. & Std. Err. & z & $\mathrm{P}>|\mathrm{z}|$ & {$[95 \%$} & Conf. & Interval] \\
\hline $\operatorname{acsiz}$ & -.0232147 & .0098459 & -2.36 & 0.018 & -.0425 & 5123 & -.0039171 \\
\hline acind & .1112985 & .071964 & 1.55 & 0.122 & -.029 & 7483 & .2523453 \\
\hline acfep & -.0936458 & .0716802 & -1.31 & 0.191 & -.234 & 1364 & .0468447 \\
\hline acmt & .0096846 & .008287 & 1.17 & 0.243 & -.006 & 5577 & .0259268 \\
\hline Invs_SQRT & -.0255277 & .0223816 & -1.14 & 0.254 & -.069 & 3948 & .0183395 \\
\hline _cons & .205453 & .0796139 & 2.58 & 0.010 & .049 & 4126 & .3614934 \\
\hline sigma_u & 0 & & & & & & \\
\hline sigma_e & .06481173 & & & & & & \\
\hline rho & & (fraction & var & ce due to & $\circ u_{-}$i) & & \\
\hline
\end{tabular}




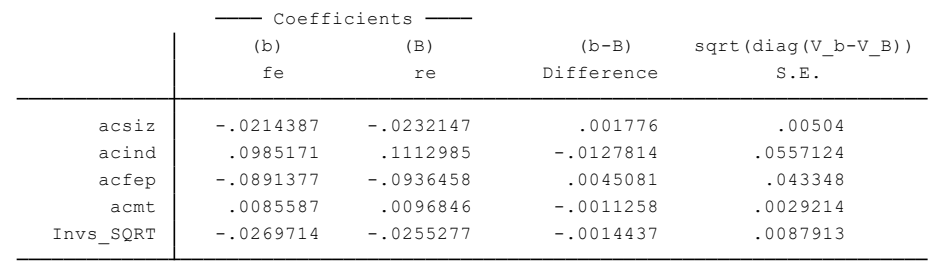

$\mathrm{b}=$ consistent under $\mathrm{HO}$ and $\mathrm{Ha}$; obtained from xtreg $B=$ inconsistent under $\mathrm{Ha}$, efficient under Ho; obtained from xtreg

Test: Ho: difference in coefficients not systematic

$$
\begin{array}{rlc}
\operatorname{chi2}(5) & = & (b-B) \cdot\left[\left(V_{-} b-V_{-} B\right)^{\wedge}(-1)\right](b-B) \\
& = & 0.31 \\
\text { Prob }>\text { chi2 } & = & 0.9974
\end{array}
$$

Breusch and Pagan Lagrangian multiplier test for random effects

$\operatorname{dcc}[$ firm, $t]=\mathrm{Xb}+\mathrm{u}[\mathrm{firm}]+\mathrm{e}[\mathrm{firm}, \mathrm{t}]$
Estimated results:
\begin{tabular}{r|rr} 
& $\operatorname{Var}$ & $\mathrm{sd}=\operatorname{sqrt}(\operatorname{Var})$ \\
\hline $\mathrm{dcc}$ & .0043071 & .0656282 \\
$\mathrm{e}$ & .0042006 & .0648117 \\
$\mathrm{u}$ & 0 & 0
\end{tabular}

Test: $\operatorname{Var}(\mathrm{u})=0$

$$
\begin{array}{rr}
\text { chibar2 }(01)= & 0.00 \\
\text { Prob }>\text { chibar2 } & =1.0000
\end{array}
$$

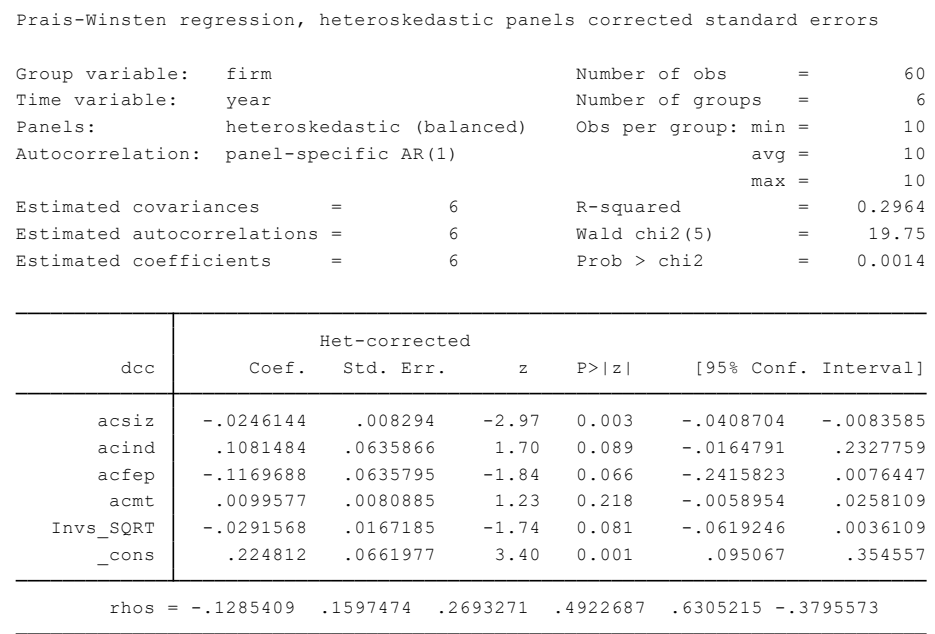

